\title{
SISTEM PENJUALAN ONLINE AIR MINUM ISI ULANG BERBASIS MOBILE
}

\author{
Septa Febriyanda ${ }^{1}$, Taufik Hidayat ${ }^{2}$, Diki Susandi ${ }^{3}$ \\ ${ }^{1,2}$ Program Studi Teknik Informatika Fakultas Teknik Universitas Islam Syekh Yusuf \\ Jln. Maulana Yusuf No. 10, Babakan - Tangerang \\ ${ }^{3}$ Program Studi Informatika Fakultas Teknologi Informasi Universitas Serang Raya \\ Jln. Raya Serang Cilegon Drangong - Serang \\ ${ }^{1}$ septafebriyanda@yahoo.com \\ 2 thidayat@unis.ac.id \\ 3 unsera.diky@gmail.com
}

\begin{abstract}
Abstrak - Penjualan online atau e-commerce merupakan mekanisme bisnis tersendiri yang sudah cukup dikenal luas. Mekanisme bisnis ini memberikan kesempatan kepada seluruh manusia di muka bumi untuk sama-sama berhasil dalam bisnis di dunia maya. CV. Tirta Lestari merupakan perusahaan yang bergerak dalam bisnis penjualan air minum is ulang. Bisnis yang dilakukan selama ini masih belum memanfaatkan mekanisme penjualan online yang berakibat banyaknya biaya yang dikeluarkan dalam melakukan promosi penjualan kepada konsumen. Tujuan penelitian ini adalah merancang dan membangun aplikasi penjualan air minum isi ulang berbasis mobile yang terhubung langsung ke website secara lengkap dengan informasi air minum beserta harga dan cara pembeliannya sehingga dapat mempermudah konsumen mencari produk air minum isi ulang dan membantu perusahaan dalam melakukan penjualan air minum isi ulang. Metode penelitian yang digunakan dalam penelitian ini adalah metode pengembangan waterfall yang meliputi komunikasi perencanaan, pemodelan, konstruksi, dan deployment. Pemodelan sistem dibuat dengan menggunakan pemodelan UML. Hasil yang dicapai berupa penerapan suatu aplikasi untuk smartphone android yang dapat mencari produk air minum, serta memberikan informasi-informasi yang dibutuhkan untuk pemesanan produk air minum isi ulang.
\end{abstract}

Kata Kunci-Penjualan Online, Android, UML, Waterfall, Air Minum.

\section{Pendahuluan}

Perkembangan teknologi pada saat ini berkembang begitu pesat, mulai dari aspek kehidupan manusia semua menggunakan teknologi. Teknologi menjadi sebuah kebutuhan yang tidak bisa lepas dari gaya hidup, bahkan pada perkembangannya manusia semakin tergantung dengan teknologi. Dalam bidang usaha, perkembangan teknologi informasi telah memberikan dampak yang cukup berarti dalam meningkatkan kegiatan usaha khususnya dalam hal pengelolaan data yang memberikan dukungan terhadap pengambilan keputusan bisnis dan dalam hal peningkatan pelayanan. Banyak perusahaan terbatas dalam memasarkan dan menjual produknya, biasanya hanya mencakup pada daerah perusahaan itu sendiri, ini disebabkan oleh pemasaran yang terbatas. Salah satu cara meningkatkan luas daerah pemasaran yaitu dengan menggunakan media internet.

Saat ini internet juga merupakan jaringan luas manusia dan informasi sehingga memungkinkan internet dapat digunakan sebagai media bisnis dalam menjalankan usahanya, yaitu menjual jasa dan produk secara online, serta memungkinkan pelanggan potensial, calon pelanggan dan mitra bisnis dapat mengakses informasi-informasi yang berkaitan dengan produk-produk dan layanan mereka sehingga pada akhirnya melakukan pembelian terhadap produk serta layanan tersebut.

Android adalah sistem informasi yang menggunakan kernel linux yang open source yang menggunakan java sebagai bahasa pemprograman sehingga memudahkan pengembang untuk membuat aplikasi di android. [1]

Aplikasi android merupakan salah satu teknologi yang sudah banyak digunakan sebagai media perdagangan antara 
perusahaan ataupun badan usaha dengan konsumen. Salah satunya yaitu menekankan pada penggunaan teknologi informasi dan komunikasi (ICT) dalam transaksi antar bisnis, antar organisasi, dan transaksi antar bisnis dengan konsumen.

Seiring dengan perkembangan teknologi mobile, media pemasaran produk mulai merambah ke perangkat mobile yang terus dikembangkan, salah satunya yang berasal dari mobile merupakan suatu sistem perdagangan elektronik yang dilakukan melalui media portabel seperti ponsel, PDA, dan lain sebagainya.

CV. Tirta Lestari adalah perusahaan yang bergerak di bidang penjualan air minum isi ulang. CV. Tirta Lestari sendiri ingin mengembangkan usahanya agar masyarakat luas dapat mengenalnya. Untuk promosi yang dilakukan masih menggunakan brosur dan spanduk, biaya yang diperlukan pun cukup tinggi. Saat ini sistem penjualan di CV. Tirta Lestari belum menggunakan suatu sistem yang terkomputerisasi, pemesanan dilakukan dengan cara konsumen datang langsung ke lokasi proses pengolahan data penjualan produk masih memerlukan waktu yang lama, disebabkan tidak teraturnya data dalam penyimpanan arsip karena masih ditulis dalam nota manual, selain itu belum tersedianya media promosi yang baik untuk memberikan informasi tentang CV.Tirta Lestari.

Berdasarkan permasalah tersebut, maka penelitian ini dilakukan dengan cara merancang dan membangun sebuah sistem penjualan online berbasis mobile pada CV. Tirta Lestari. Hasil penelitian dapat langsung diterapkan dalam proses penjualan air minum isi ulang serta penyebaran informasi-informasi yang terkait dengan penjualan. Diharapkan dengan adanya sistem ini akan dapat membantu perusahaan dalam mengolah transaksi penjualan dan memudahkan dalam proses promosi produk air minum isi ulang serta memudahkan konsumen dalam mencari informasi tentang pemesanan air minum isi ulang.

\section{Metodologi Penelitian}

\section{A. Model Pengembangan Sistem Informasi}

Model pengembangan sistem informasi yang digunakan dalam penellitian ini adalah dengan menggunakan model waterfall. Metode air terjun atau yang sering disebut metode waterfall sering dinamakan siklus hidup klasik (classic life cycle), dimana hal ini menggambarkan pendekatan yang sistematis dan juga berurutan pada pengembangan perangkat lunak, dimulai dengan spesifikasi kebutuhan pengguna lalu berlanjut melalui tahapan-tahapan perencanaan (planning), permodelan (modeling), konstruksi (construction), serta penyerahan sistem ke para pelanggan/pengguna (deployment), yang diakhiri dengan dukungan pada perangkat lunak lengkap yang dihasilkan. Tahapan metode waterfall dapat dilihat pada gambar di bawah ini. [2]

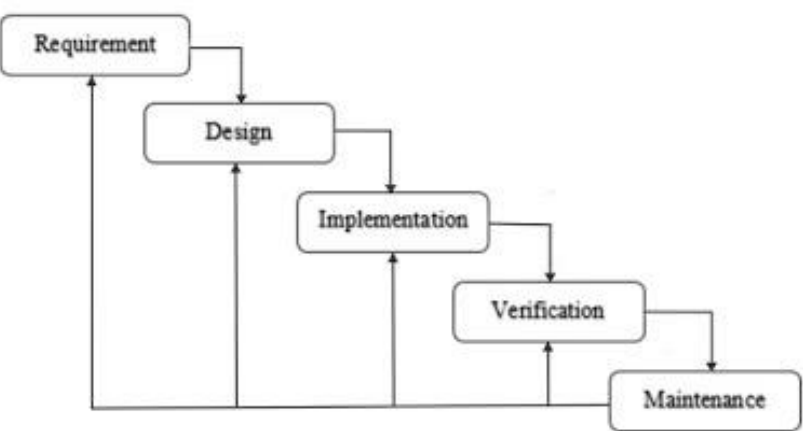

Gambar 1. Tahapan Model Waterfall

B. Metode Pengumpulan Data

Metode pengumpulan data dalam penelitian ini adalah sebagai berikut:

1) Studi Literatur: Pada penelitian pembuatan aplikasi ini di perlukan metode pendekatan sistem penyelesaian persoalan yang di mulai dengan dilakukannya identifikasi terhadap adanya sejumlah kebutuhankebutuhan, sehingga dapat menghasilkan suatu operasi dari sistem yg dianggap efektif oleh penulis. Dalam metode ini peneliti mengumpulkan berbagai data dan informasi yang berkaitan dengan penelitian melalui buku, jurnal, internet dan situs-situs internet. Peneliti mengumpulkan data mengenai Atom, XAMPP, Genymotion, Android Studio.

2) Metode Spasial: Metode ini digunakan untuk mendapatkan suatu sistem penjualan yang terkomputerisasi.

\section{Metode Analisa Data}

Pada metode analisa data terdapat metode-metode yang digunkan diantaranya sebagai berikut:

1) Survey Data: Pada metode ini peneliti melakukan survey lokasi langsung terkait dengan pengambilan data-data perusahaan.

2) Hasil Survey: Data hasil survey yang sudah terkumpul di-input ke dalam software microsoft excel berupa datadata penjualan air minum isi ulang.

3) Data Lengkap: Semua data mengenai produk yang dijual dikumpulkan secara detail dan kemudian di-input ke dalam database penjualan.

\section{Metode Pengujian Sistem}

Setelah perangkat lunak dibuat dengan menggunakan bahasa pemrograman Android, perangkat lunak perlu diuji dan diaplikasikan untuk memastikan kesesuaian sistem dengan desain dan semua fungsi dapat digunakan dengan baik.

Pengujian dilakukan dengan menggunakan metode pengujian blackbox testing, yaitu menguji perangkat lunak tanpa memperhatikan kodingnya, hanya menguji masukan dan keluaran saja. Pengujian blackbox berusaha untuk menemukan 
kesalahan dalam beberapa kategori, diantaranya: fungsi-fungsi yang salah atau hilang, kesalahan interface, kesalahan dalam struktur data atau akses database eksternal, kesalahan performa, kesalahan inisialisasi dan terminasi. [3]

Dalam pengujian ini digunakan teknik pengujian equivalence partitioning yang mana pengujian ini memberikan input-an dan memeriksa apakah output yang dihasilkan sesuai dengan apa yang diharapkan atau masih terdapat error.

Pengujian pada blackbox berusaha menemukan kesalahan seperti:

1) Fungsi-fungsi yang tidak benar atau hilang.

2) Kesalahan interface.

3) Kesalahan dalam struktur data atau akses database eksternal.

4) Kesalahan kinerja.

5) Inisialisasi dan kesalahan terminasi

\section{HASIL DAN PEMBAHASAN}

\section{A. Hasil Penelitian}

Dalam tahapan ini menjelaskan hasil dari perancangan sistem serta uji coba yang telah dilakukan dari sistem yang telah selesai dirancang dan dapat digunakan. Hasil sistem yang dibuat merupakan sebuah aplikasi penjualan online air minum isi ulang pada CV. Tirta Lestari serta pencarian khusus di Wilayah Tangerang.

Aplikasi ini dibuat menggunakan software android studio sebagai Java IDE (Integrated Development Environment) dalam pembuatan program pada aplikasi penjualan online air minum isi ulang. Android Nougat 7.1.1 (SDK 27) sebagai alat bantu dan API untuk mengembangkan aplikasi ini.

\section{1) Perancangan Dengan Use Case Diagram}

Use case adalah suatu pola atau gambaran yang menunjukan kelakukan atau kebiasaan sistem. Use case merupakan sebuah teknik yang digunakan dalam pengembangan sebuah software atau sistem informasi untuk menangkap kebutuhan fungsional dari sistem yang bersangkutan. Use case diagram menjelaskan interaksi yang terjadi antara aktor serta inisiator dari interaksi sistem itu sendiri dengan sistem yang ada. Sebuah use case direpresentasikan dengan urutan langkah yang sederhana. [4]

Adapun use case diagram pada perancangan sistem penjualan online air minum isi ulang ini sebagai berikut:

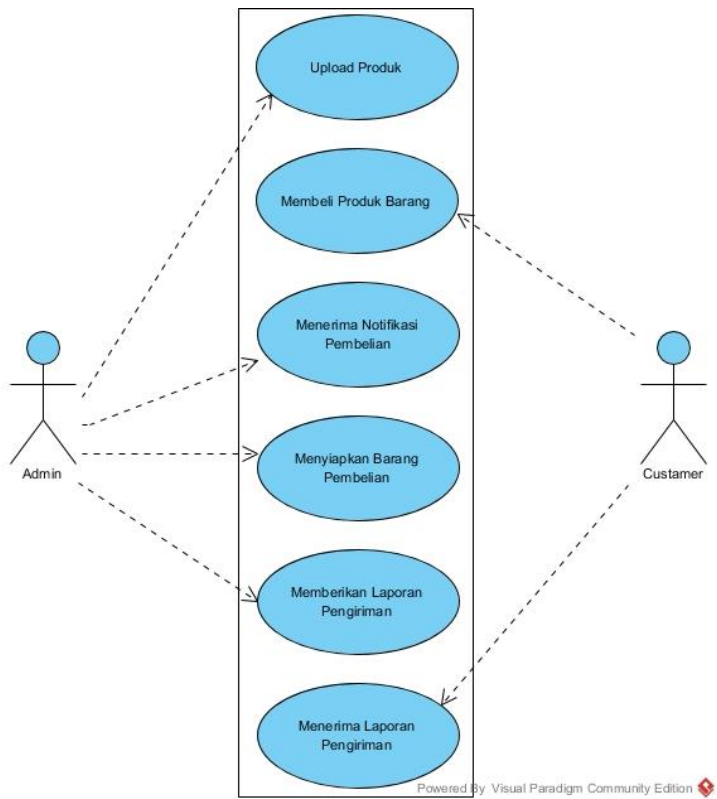

Gambar 2. Diagram Use Case Perancangan Sistem

\section{2) Perancangan Dengan Activity Diagram}

Activity Diagram adalah diagram yang menggambarkan workflow (aliran kerja) atau aktivitas dari sebuah sistem atau proses bisnis. Komponen yang ada pada activity diagram antara lain : Activity atau state : Menunjukan aktivitas yang dilakukan. Initial activity atau initial state : Menunjukan awal aktivitas dimulai. [5]

Adapun activity diagram pada perancangan sistem penjualan online air minum isi ulang ini sebagai berikut:

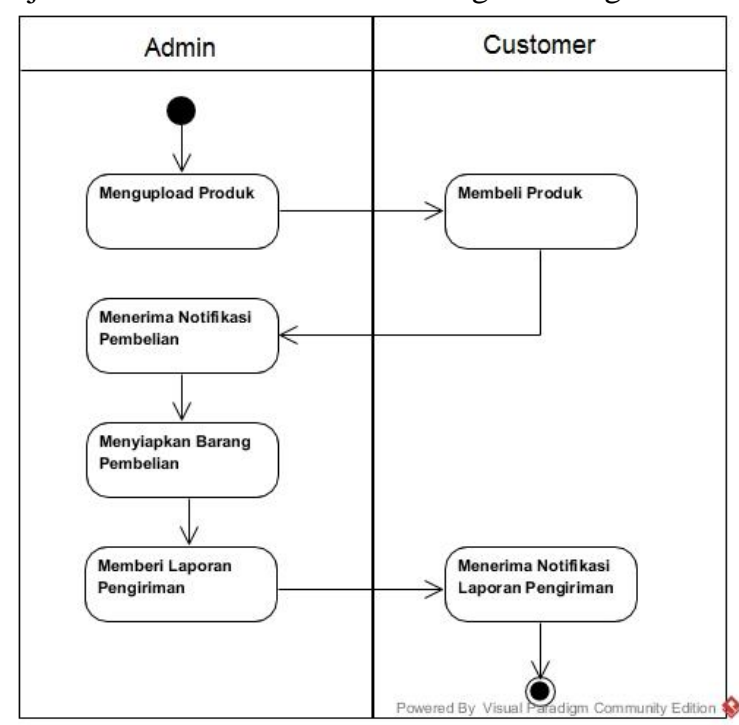

Gambar 3. Diagram Activity Perancangan Sistem 


\section{B. Implementasi Sistem}

Implementasi sistem dilakukan setelah tahap perancangan sistem selesai dilakukan. Implementasi ini dilakukan untuk menyelesaikan sistem yang ada pada rancangan sistem dan desain interface yang telah disetujui. Berikut adalah hasil implementasi sistem:

\section{1) Class Diagram dan Layout Sistem}

Tabel 1

Class Diagram Sistem

\begin{tabular}{|c|c|c|}
\hline No. & Class & Fungsi \\
\hline 1 & ActivityHome.java & $\begin{array}{l}\text { Class untuk } \\
\text { menampilkan menu } \\
\text { utama aplikasi }\end{array}$ \\
\hline 2 & $\begin{array}{l}\text { ActivityCategoryList.jav } \\
\text { a }\end{array}$ & $\begin{array}{l}\text { Class untuk } \\
\text { menampilkan daftar } \\
\text { kategori produk }\end{array}$ \\
\hline 3 & ActivityMenuList.java & $\begin{array}{l}\text { Class untuk } \\
\text { menampilkan isi dari } \\
\text { kategori produk }\end{array}$ \\
\hline 4 & ActivityMenuDetail.java & $\begin{array}{l}\text { Class untuk } \\
\text { menampilkan rincian } \\
\text { produk }\end{array}$ \\
\hline 5 & ActivityCart.java & $\begin{array}{l}\text { Class untuk } \\
\text { menampilkan daftar } \\
\text { belanja produk }\end{array}$ \\
\hline 6 & ActivityCheckout.java & $\begin{array}{l}\text { Class untuk } \\
\text { menampilkan formulir } \\
\text { data }\end{array}$ \\
\hline 7 & $\begin{array}{l}\text { ActivityConfirmMessag } \\
\text { e.java }\end{array}$ & $\begin{array}{l}\text { Class untuk } \\
\text { menampilkan } \\
\text { pemberitahuan } \\
\text { konfirmasi }\end{array}$ \\
\hline 8 & ActivitySplash.java & $\begin{array}{l}\text { Class untuk } \\
\text { menampilkan layar } \\
\text { splash }\end{array}$ \\
\hline 9 & DbHelper.java & $\begin{array}{l}\text { Class untuk } \\
\text { menghubungkan data } \\
\text { dari database }\end{array}$ \\
\hline 10 & Constant.java & $\begin{array}{l}\text { Class untuk } \\
\text { menghubungkan admin } \\
\text { web dengan app }\end{array}$ \\
\hline 11 & ActivityProfile.java & $\begin{array}{l}\text { Class untuk } \\
\text { menampilkan profil } \\
\text { perusahaan }\end{array}$ \\
\hline 12 & ActivityAbout.java & $\begin{array}{l}\text { Class untuk } \\
\text { menampilkan versi dari } \\
\text { aplikasi }\end{array}$ \\
\hline
\end{tabular}

Tabel 2

Layout Sistem

\begin{tabular}{|c|c|c|}
\hline No & Layout & Fungsi \\
\hline 1 & main_menu_item.xml & $\begin{array}{l}\text { Layout untuk menu utama } \\
\text { aplikasi }\end{array}$ \\
\hline 2 & $\begin{array}{l}\text { category_list_item.xm } \\
1\end{array}$ & $\begin{array}{l}\text { Layout untuk daftar kategori } \\
\text { produk }\end{array}$ \\
\hline 3 & menu_list.xml & $\begin{array}{l}\text { Layout untuk menampilkan } \\
\text { isi dari kategori produk }\end{array}$ \\
\hline 4 & menu_detail.xml & Layout untuk rincian produk \\
\hline 5 & order_list_item.xml & $\begin{array}{l}\text { Layout untuk menampilkan } \\
\text { daftar belanja produk }\end{array}$ \\
\hline 6 & checkout.xml & $\begin{array}{l}\text { Layout untuk menampilkan } \\
\text { formulir data }\end{array}$ \\
\hline 7 & confirm.xml & $\begin{array}{l}\text { Layout untuk menampilkan } \\
\text { pemberitahuan konfirmasi }\end{array}$ \\
\hline 8 & splash.xml & $\begin{array}{l}\text { Layout untuk menampilkan } \\
\text { layar splash }\end{array}$ \\
\hline 9 & about.xml & $\begin{array}{l}\text { Layout untuk menampilkan } \\
\text { versi dari aplikasi }\end{array}$ \\
\hline 10 & your_order.xml & $\begin{array}{l}\text { Layout untuk menampilkan } \\
\text { daftar produk yang dibeli }\end{array}$ \\
\hline 11 & contact_us.xml & $\begin{array}{l}\text { Layout untuk menampilkan } \\
\text { kontak perusahaan }\end{array}$ \\
\hline 12 & grid_item.xml & $\begin{array}{l}\text { Layout untuk menyusun } \\
\text { daftar kategori }\end{array}$ \\
\hline 13 & $\begin{array}{l}\text { nav_drawer_main.xm } \\
1\end{array}$ & $\begin{array}{l}\text { Layout untuk menyusun menu } \\
\text { utama }\end{array}$ \\
\hline
\end{tabular}

2) Tampilan Interface SplashScreen Sistem

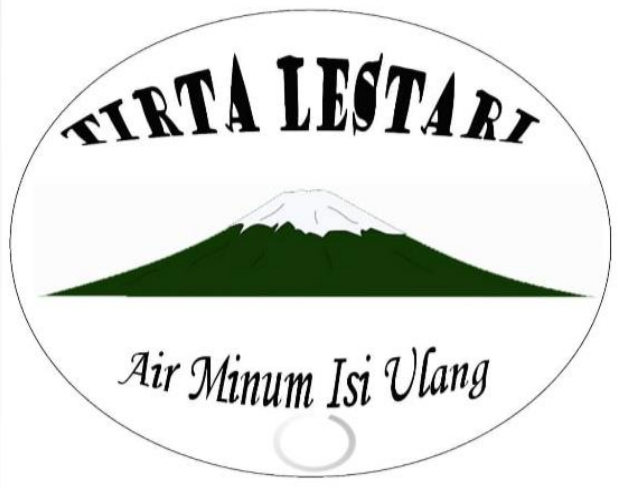

Gambar 4. Interface SplashScreen 


\section{3) Tampilan Interface Menu Utama User}

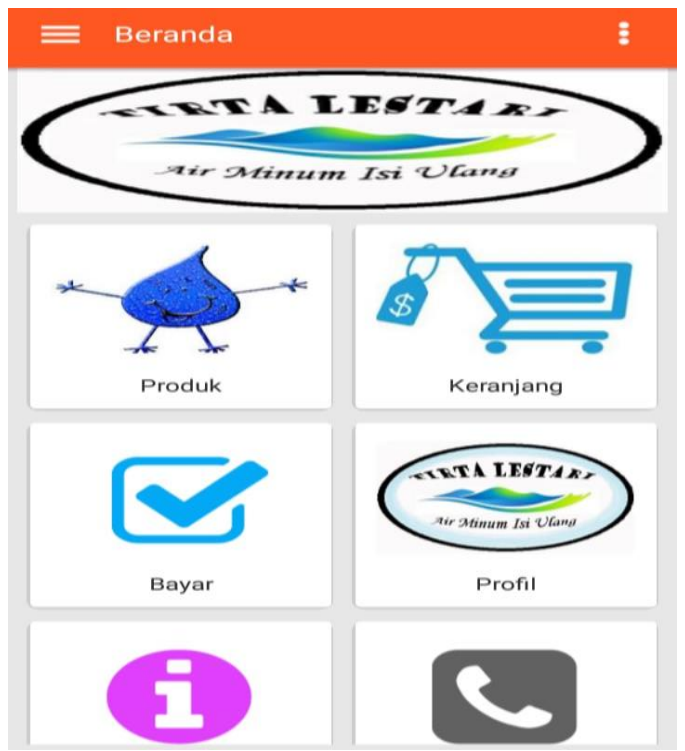

Gambar 5. Interface Menu Utama User

4) Tampilan Interface Splash Screen Login Admin

\section{Login Administrator}

(E-Commerce Android App)

Username :

admin

\section{Password:}

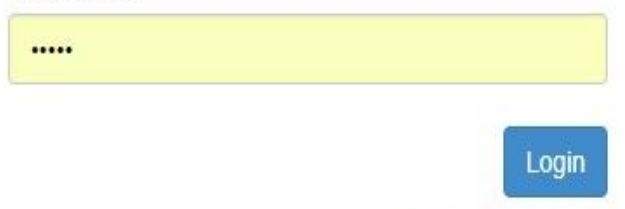

Forgot Password?

Gambar 6. Interface SplashScreen Login Admin

\section{5) Tampilan Interface Menu Utama Admin}

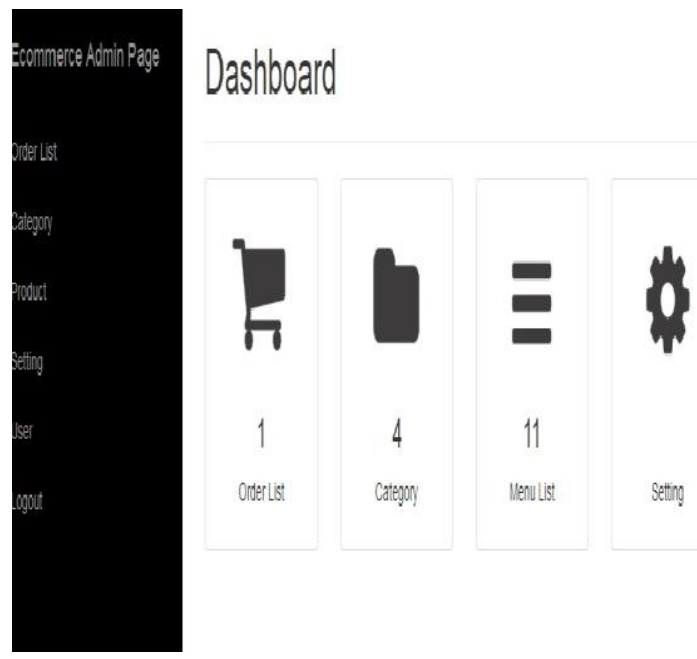

Gambar 7. Interface Menu Utama Admin

\section{Pengujian Sistem}

Proses pengujian aplikasi penjualan online berbasis android ini dilakukan untuk mengetahui hasil dari perancangan sistem yang telah dibuat, baik itu dari segi interface design maupun sistem pemrogramannya. Proses uji coba kinerja aplikasi berkaitan dengan kecepatan dan spesifikasi dari jenis sistem operasi yang dapat digunakan untuk menjalankan aplikasi.

Adapun hasil pengujian sistem pada perancangan aplikasi yang telah dilakukan dapat dilihat pada tabel berikut:

Tabel 3

Hasil Pengujian Blackbox

\begin{tabular}{|c|c|c|c|c|}
\hline No & Pengujian & Tes Case & $\begin{array}{c}\text { Hasil Yang } \\
\text { Di harapkan }\end{array}$ & $\begin{array}{c}\text { Hasil } \\
\text { Pengujian } \\
\end{array}$ \\
\hline 1 & $\begin{array}{c}\text { Menjalankan } \\
\text { Aplikasi }\end{array}$ & $\begin{array}{c}\text { Load } \\
\text { SplashScreen }\end{array}$ & $\begin{array}{c}\text { Aplikasi } \\
\text { dapat } \\
\text { berjalan } \\
\text { dengan } \\
\text { menampilkan } \\
\text { splashscreen } \\
\text { dari aplikasi } \\
\text { Tirta Lestari. }\end{array}$ & $\begin{array}{c}\text { Sesuai } \\
\text { Dengan } \\
\text { Yang } \\
\text { Diharapkan }\end{array}$ \\
\hline 2 & $\begin{array}{l}\text { Memilih } \\
\text { Produk }\end{array}$ & $\begin{array}{c}\text { Menampilkan } \\
\text { Daftar } \\
\text { Kategori }\end{array}$ & $\begin{array}{c}\text { Aplikasi } \\
\text { dapat } \\
\text { menampilkan } \\
\text { daftar } \\
\text { Kategori } \\
\text { produk. }\end{array}$ & $\begin{array}{c}\text { Sesuai } \\
\text { Dengan } \\
\text { Yang } \\
\text { Diharapkan }\end{array}$ \\
\hline 3 & $\begin{array}{l}\text { Memilih } \\
\text { Sub Menu } \\
\text { Kategori }\end{array}$ & $\begin{array}{l}\text { Menampilkan } \\
\text { daftar produk }\end{array}$ & $\begin{array}{c}\text { Aplikasi } \\
\text { dapat } \\
\text { menampilkan } \\
\text { daftar produk }\end{array}$ & $\begin{array}{c}\text { Sesuai } \\
\text { Dengan } \\
\text { Yang } \\
\text { Diharapkan }\end{array}$ \\
\hline 4 & $\begin{array}{l}\text { Memilih sub } \\
\text { menu }\end{array}$ & $\begin{array}{l}\text { Menampilkan } \\
\text { rincian }\end{array}$ & $\begin{array}{c}\text { Aplikasi } \\
\text { dapat }\end{array}$ & $\begin{array}{c}\text { Sesuai } \\
\text { Dengan }\end{array}$ \\
\hline
\end{tabular}




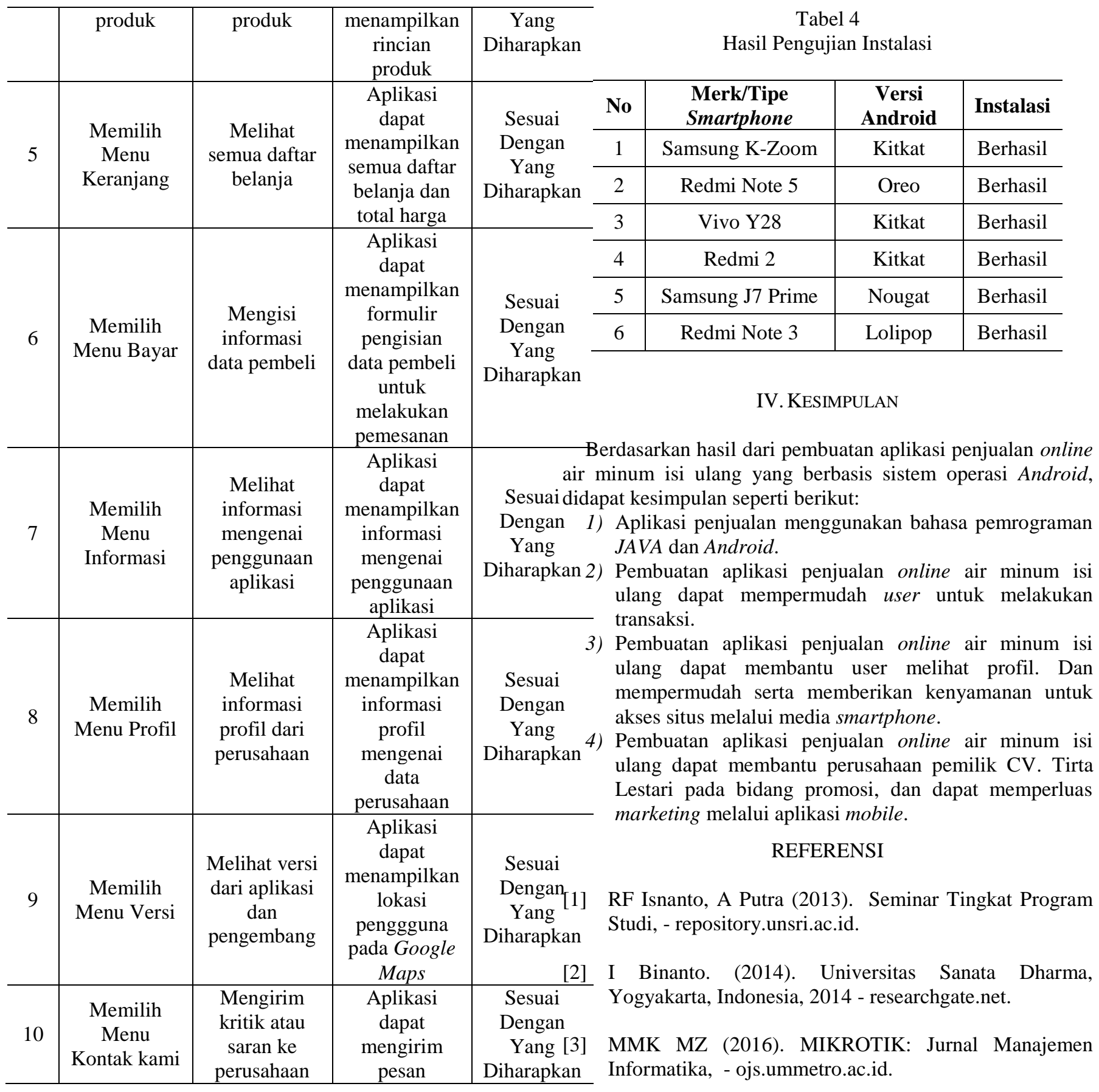

Tahap pengujian selanjutnya adalah dengan melakukan instalasi pada beberapa merk/tipe smartphone bersistem operasi Android. Berikut adalah tabel hasil pengujian instalasi pada smartphone bersistem operasi Android:
[4] Henderi. (2007). Analysis and Design System with Unified Modeling Language (UML). Tangerang.

[5] Y Simaremare, A Pribadi, RP Wibowo. (2013). Jurnal Teknik ITS - ejurnal.its.ac.id.

[6] https://www.qwords.com/blog/jumlah-pengguna-internetdi-indonesia/ (diakses pada tanggal 3 Februari 2020). 